Киселев С.B. ${ }^{2}$

\title{
О ходе Дохийского раунда многосторонних торговых переговоров урегулирования сельского хозяйства
}

По общим вопросам Дохийского раунда переговоры фактически прекратились, несмотря на все активные попытки их возобновить. По этому поводу прошли два заседания Генерального совета. Один Генеральный совет был в октябре, другой - в конце ноября. Какая здесь ситуация? Сформировалось две позиции по Дохийскому раунду. Первая - что надо продолжать, отталкиваясь от тех документов, которые к настоящему моменту уже подготовлены. Последние документы относятся к концу 2008 г., так называемые модальности (modalities). Фактически это калька основных решений, обязательные вопросы для обсуждения. Но они уже в очень подробном виде. Развивающиеся страны, в частности Бразилия и др., говорят о том, что в проекте модальностей декабря 2008 г. многие вещи уже окончательно согласованы и просто надо продолжать эту работу.

Вторая позиция связана с тем, что прошел уже большой срок с начала переговоров и многое изменилось, и потому необходимо начать подготовку

2 Киселев Сергей Викторович - заведующий кафедрой агроэкономики экономического факультета МГУ им. М.В. Ломоносова, доктор экономических наук, профессор. 
новых документов, в том числе и модальностей по сельскому хозяйству. Данного подхода придерерживаются некоторые развитые страны.

Следует отметить, что научное сообщество продолжает работать по проблемам Дохийского раунда. Перед октябрьским заседанием Генерального совета по линии Международного центра по торговле и устойчивому развитию (International Center for Trade and Sustainable Development, ICTSD) при поддержке ФАО состоялись обсуждения. Один день посвятили вопросам экспертов, а второй день - так называемому диалогу. На заседании присутствовали представители практически всех миссий, в том числе и российской.

Кроме того, присутствовали несколько действующих послов, а также некоторые бывшие послы стран - членов ВТО. В качестве эксперта, например, приехал бывший руководитель переговоров по сельскому хозяйству Кроуфорд Фалконер, сейчас возглавляющий проект в ОЭСР по вопросам торговли услугами. Присутствовали бывший профессор Гарвардского университета Питер Тиммер, очень известный специалист в области сельского хозяйства, а также Джеймс Моррисон из ФАО.

Таким образом, вопросы продолжения переговоров активно обсуждаются как на экспертном уровне, так и на политическом. Работа идет на различных площадках: национальных и международных.

В этой области был очень интересный и плодотворный разговор. Ознакомиться с содержанием которого можно на сайте ICTSD ${ }^{1}$. Кроме того, выпущен сборник (Tackling agriculture in the post-Bali context), в котором представлены аналитические статьи, связанные с состоянием переговоров, позицией разных стран и другими темами.

Как отмечают некоторые эксперты, касаясь вопросов перспектив Дохийского раунда, можно было бы сдвинуть переговоры с мертвой точки, но в основном все зависит от политической воли. Политическая неопределенность в отдельных ведущих странах является серьезным препятствием, по крайней мере в ближайшие несколько лет. Это касается основных проблемных точек по сельскому хозяйству. В то же время никто радужных перспектив Дохийского раунда не предсказывал.

По второй позиции многое определяется тем, что развитые страны не очень довольны предварительными документами по сельскому хозяйству и, по мнению их представителей, в связи с изменением ситуации надо очень многое поменять. Примерно таково общее положение дел в переговорном процессе.

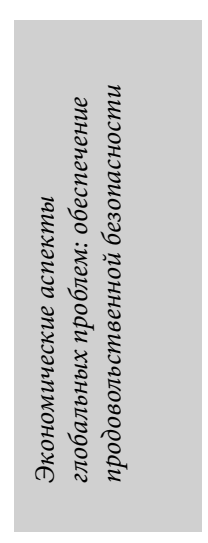

$1<w w w . i c t s d . o r g>$. 
Из размещенных на сайте ВТО материалов нетрудно заметить, что возросла частота заседаний Генерального совета: теперь они проходят практически каждый месяц. Идут интенсивные консультации. Каждый раз появляются надежды, подогреваемые тем, что в конце 2015 г. состоится десятая юбилейная Министерская конференция в Найроби (Кения). К ней нужны документы. Но Рабочего плана по продвижению переговоров пока нет. Практического движения пока тоже не зафиксировано.

Какие факторы здесь работают помимо чисто переговорных позиций? При обсуждении этих вопросов прежде всего называлась политическая составляющая. Чтобы принимать решения, должны быть политики, обладающие реальными возможностями для этого. Отмечалось, например, что у США в лице президента Обамы сейчас нет такой возможности. Кроме того, позиция администрации Обамы в настоящее время не очень сильная, что видно по результатам выборов. Демократы практически проиграли выборы в Конгресс, потеряли большинство, причем в обеих палатах Конгресса. Поэтому вероятность того, что у Обамы будет что-то типа fast track, возможности принимать решение, которое заранее одобрено Конгрессом, — очень низка.

К этому специалисты добавляли, что в связи с данной ситуацией и с тем, что следующие выборы президента США только в ноябре 2016 г., американцы не будут принимать каких-либо окончательных решений до выборов. Такова политическая ситуация по Дохийскому раунду.

Иногда говорят, что США определяют все решения. Конечно, это не так, это неправильное мнение. США - очень влиятельный член ВТО, но в современных условиях при существующей практике принятия решений в организации они не могут одни обеспечить решение. США влияют, но не решают.

Практика вступления Российской Федерации в ВТО показывает, что нам надо было договариваться не только с США и ЕС, но и со многими другими странами. Все большее значение имеют развивающиеся страны, в том числе Бразилия, Индия и др. По сельскому хозяйству, например, на конечном этапе мы договаривались с такими странами, как Бразилия, Колумбия, Таиланд, Пакистан и др. Некоторые обязательства по сельскому хозяйству прямо были связаны с требованиями развивающихся стран. Например, на каком-то этапе Бразилия выдвинула дополнительные требования, которые вылились в дополнительные обязательства Российской Федерации. Так, помимо снижения объемов поддержки сельского хозяйства с 9,0 до 4,4 млрд долл., у России есть обязательства по соблюдению соотношения мер продуктово-специфической и продуктово-неспецифической поддержки до 2017 г. включительно, что связано с возможностями оказания поддержки в 9 млрд долл. в 2012-2013 гг., а также высоким разрешенным уровнем поддержки в последующие годы. В результате у ряда стран возникли опасения, что эти возможности мы используем на продуктово-специфическую поддержку. 
В отношении Европейского Союза тоже существует политическая составляющая переговоров. Смена руководителя Европейской комиссии, комиссаров по вопросам сельского хозяйства и торговли требует времени для ознакомления с делами, а новые люди привносят новые аспекты и мнения.

И еще одна составляющая, сдерживающая нахождение компромиссов в процессе Дохийского раунда, - это экономическая ситуация в различных странах. В США экономическая ситуация налаживается, а вот в Европейском Союзе и Японии не все благополучно. В ЕС до сих пор рост менее $1 \%$. Конечно, в условиях такого роста очень сложно принимать компромиссные решения. При таких решениях и уступках, например, развивающимся странам, появится сильная критика как оппозиции, так и профсоюзов.

К этому добавляется сложная архитектура самого Дохийского раунда, что тоже называют в качестве одной из причин, длительного ведения переговоров. Если сравнить повестку дня Уругвайского раунда с повесткой дня Дохийского раунда, нетрудно заметить очевидность сложности и разнообразности современных переговоров. Тем не менее, по-видимому, и здесь можно договориться. Это общая атмосфера Дохийского раунда. При этом для описания ситуации используется более мягкое английское слово impasse.

Что же касается сельского хозяйства, то в рамках Балийского пакета и Дохийского раунда существуют сложные вопросы. Прежде всего закупка резервов для целей продовольственной безопасности. Следует обратить внимание на тот факт, что США и Индия пришли к компромиссу1, окончательного решения не найдено, т.е. постоянного решения нет. При этом Индия оказалась ключевым игроком.

Здесь необходимо отметить следующую общую ситуацию по Дохийскому раунду, что также осложняет переговоры: развивающие страны - члены ВТО стали самостоятельными участниками, они ощущают свою силу, формулируют и отстаивают свою точку зрения и свои позиции, которые не всегда бывают единообразными.

По продовольственной безопасности в рамках Балийских договоренностей нашли следующие решения. Первое - продолжить переговоры до постоянного решения. Второе - по Индии не будет каких-то споров о нарушении правил, к ней не будут применять механизм разрешения споров, если чтото будет нарушаться. Это такое компромиссное решение, но оно временное. Правда, мы знаем, что нет ничего постояннее временных решений. Но в данном случае с формальной точки зрения оно все равно пока непостоянное

1 Подробнее можно ознакомиться с решением Генерального совета от 27 ноября 2014 г. на сайте организации. 
и отложено до решения всего комплекса переговоров Дохийского раунда. При возобновлении переговоров тема Индии, безусловно, опять возникнет.

Позиция Индии состоит в том, что она хочет закупать рис для создания запасов без каких-либо ограничений. Причем она подчеркивала, что не вообще закупает рис, а именно для бедных слоев населения - это ее логика. Логика же и сомнения США и Канады заключаются в том, что Индия закупает рис в запасы и одновременно экспортирует его. Это один из аргументов против того, чтобы разрешить Индии закупать, на что индийцы отвечают: «В запасы мы закупаем один сорт риса, а продаем другой сорт».

Кроме того, в сельском хозяйстве существует проблема цен. Индийцы говорят, что по рыночным ценам закупают и ничего не нарушают. По мнению же второй стороны, тех же США и Канады, Индия этими закупками не просто облегчает одновременный экспорт, а оказывает поддержку сельскохозяйственному производителю, на что индийцы дают отрицательный ответ. Вот тут возникает вопрос методологии оценки существования или отсутствия ценовой поддержки. Развитые страны исходят из цен, зафиксированных в ходе Уругвайского раунда, а Индия апеллирует к современным ценам, при использовании которых не прослеживается поддержки. Такова логика их спора.

Это - системная проблема, поскольку не зафиксировано использование каких-либо новых временных́ периодов для определения поддержки цен. Формально решения Уругвайского раунда продолжают действовать, потому-то перманентного решения и нет.

Это похоже на трактовки некоторых российских обзательств. Соотношение продуктово-специфической и продуктово-неспецифической поддержки можно считать по-разному, так как методология расчета не зафиксирована, обосновывая это определенными документами и логикой.

Следующий спорный вопрос по сельскохозяйственной повестке дня - соглашение по хлопку, фактически касающееся четырех слаборазвитых африканских стран и США. Дело в том, что США, несмотря на неконкурентоспособность производства своего хлопка, продолжает его поддерживать, имея финансовые возможности. В принципе возможность ограничения такого субсидирования уже заложена в модальностях. Однако, хотя объемы производства североамериканского хлопка и незначительны, это политически является чувствительным для США. Практика показывает, что даже в случае экономической нечувствительности вопроса его политическая стоимость для США остается довольно большой.

Наиболее трудноразрешимым вопросом, в том числе в связи с существованием обязательств Уругвайского раунда, является механизм специальных защитных мер. Он был предложен по требованию развивающихся стран. Последние как раз и упирают на то, что нынешний раунд планировался 
как раунд развития. Поэтому развивающиеся страны хотят получить максимальные уступки. Но, в свою очередь, развитые страны хотят получить экономический выигрыш от результатов переговоров.

Какая проблема в механизме специальных защитных мер? Многие вопросы там согласованы, но есть один ключевой вопрос - системный. С точки зрения развитых стран по своему действию специальный защитный механизм очень похож на специальные защитные меры, прописанные в ст. 5 Соглашения по сельскому хозяйству.

При действии специального защитного механизма при определенных условиях (если разрешить развивающимся странам в полной мере применять этот механизм) таможенные пошлины по продуктам, подпадающим под его действие, будут выше тех, что разрешены Уругвайским раундом. Против этого категорически выступают развитые страны. Они считают, что таможенные пошлины не должны превышать уровня, оформленного обязательствами Уругвайского раунда. Вот здесь и кроется серьезное противоречие между двумя крупными группами стран: развитыми странами и развивающимися. Каких-то явных возможностей для компромисса в этом вопросе пока не видно, так как это неприемлемо для развитых стран.

Остальные вопросы, которые по Балийскому пакету связаны с сельским хозяйством, - вопросы экспортного регулирования. В наибольшей степени эти вопросы связаны с торговой политикой Европейского Союза, за последние годы проведшего большую реформу в данной области, в частности в области экспортных субсидий.

Данные статистики свидетельствуют, что в последние годы ЕС в незначительных масштабах применяет экспортное субсидирование, сокращая излишнее производство и избыток продукции. В Европейском Союзе изменилась система внутренней поддержки, которая все больше относится к так называемому «зеленому ящику».

Говоря о других вопросах, следует обратить внимание на фактическую ситуацию с Балийским пакетом. Одним из самых главных его достижений была договоренность о Соглашении по упрощению процедур. Для того чтобы это Соглашение вошло в силу, его должны ратифицировать $2 / 3$ членов ВТО. Формально к 10 декабрю 2014 г. только Гонконг уведомил о ратификации данного Соглашения. Есть информация о процессе ратификации еще около 50 стран. При наличии 160 членов в ВТО это составляет около $31 \%$, т.е. пока процесс далек от завершения, хотя прошло уже более года.

В целом можно сказать, что к настоящему моменту пока не видно перспектив для завершения Дохийского раунда, в том числе и по сельскому хозяйству. Но в то же время предпринимаются усилия для выработки к июлю 2015 г. Рабочей программы по повестке дня Дохийского раунда. Лакмусовой бумагой 
будет Министерская конференция в декабре 2015 г., которая не сможет обойти эту важную проблему, влияющую на многие вопросы торговой политики.

Kiselev S. ${ }^{1}$

Negotiations on agriculture in Doha round

\section{Экспортные ограничения сельскохозяйственной продукции, продовольственная безопасность и $\mathrm{BTO}^{2}$}

\section{Введение}

Широко известно, что экспортные ограничения обостряют проблему продовольственной безопасности в условиях непредсказуемого и быстрого роста цен на продукты питания, но несмотря на это, экспортные ограничения не являются основной причиной продовольственной безопасности бедных в развивающихся странах.

Ограничения сельскохозяйственного экспорта остаются недостаточно регулируемыми в рамках соглашений Уругвайского раунда и в настоящее время

1 Kiselev Sergey - the Head of Agricultural Economics Board in Economic Faculty of Lomonosov Moscow State University, Doctor of Science, professor.

2 Международный иентр по торговле и устойчивому развитию (МЦТУР) (Женева, Швейцария): Программа МЦТУР по вопросам торговли сельскохозяйственной продукиией и устойчивого развития, 2014. Этот материал подготовлен на основе анализа профессора Джованни Анания «Ограничения экспорта сельскохозяйственной продукции и ВТО: какие опщии доступны для обеспечения продовольственной безопасности?». 